\title{
IS ESCHATOLOGIE CONCREET?
}

\author{
DR. C. A. TUKKER (LEIDEN)
}

\section{INLEIDING}

In zijn overzichtelijke studie Eschatologie en futurologie ${ }^{1}$ ) zegt de Utrechtse hoogleraar C. Graafland op het eind: „Het zou wel eens kunnen zijn, dat de beslissingen tenslotte vallen in de beoordeling van de hermeneutische sleutel, die wordt gehanteerd". Waar hij eindigt, wil ik beginnen en de vraag stellen: welke zekerheid biedt het Nieuwe Testament in teksten en het verstaan van die teksten over de concreetheid van de christelijke verwachting c.q. hoop? Op zichzelf is het niet aan twyijfel onderhevig dat de hoop vast en zeker moet zijn, wil er sprake zijn van hoop. De hoop beschaamt niet. Maar het is de grote vraag: waarop richt zich die vaste hoop? $\mathrm{Zij}$ is kennelijk volgens de Brieven van het N.T. onderdeel van het geloof, toespitsing van het geloof, ${ }^{2}$ ) richting van het geloof op de toekomst. Maar is daar niet reeds mee gezegd, dat sommige dingen tot die vaste hoop behoren, andere niet? En dan rijst een andere vraag: die dingen die wij vermoeden doch niet in geloof kunnen wéten, die dingen die sómmigen vermoeden en anderen niet (neem het onderscheid tussen voorlaatste en laatste dingen), die dingen die sommigen verwachten en anderen niet (het chiliasme), behoren die tot de adiaphora of zijn ze zó wezenlijk en liggen ze zó in de Bijbelse prediking verankerd, dat ze niet te ontberen zijn in de christelijke toekomstverwachting?

Een zaak van hermeneutiek. Welke taal spreekt de Bijbel als het over de toekomstige aangelegenheden en gebeurtenissen gaat? Een apokalyptische taal of een eschatologische taal? Is er sprake van een onderscheid tussen de voorlaatste dingen waarover apokalyptisch-beeldend en de laatste dingen waarover eschatologisch thetisch gesproken wordt? Of is elke aanduiding van een totaal nieuwe, andere toekomst en schepping, een recreatio e nihilo, niet anders dan een droombeeld, een romantisch-christelijke verpakking, die van het feitelijke ontdaan moet worden, wil het kerygma voor de toekomst overblijven? Ligt het in de aard van de Bybel, dat zijn eschatologische taal ,ontmythologisiert' wil worden? Inmiddels is het ons allen duidelijk dat wij niet objectief tegenover en temidden van deze vragen kunnen staan, omdat het ónze zaak is, die hier ter sprake komt, én omdat wij leven in de spanning tussen het voorlaatste en het laatste heilsfeit: Pinksteren en wederkomst, Pinksteren en wederopstanding des vleses. Het gaat dus niet alleen om hermeneutische regels, maar ook om geloof, ,hopelijk' óns geloof!

1) Theologia Reformata jrg. XIV no. 4, Dec. 1971, blz. 292 e.v.

2) Bultmann in Th. W.N.T. II s.v. elpis. 
I. Wie de woordengroep elpis en elpidzein in het N.T. bekijkt, ${ }^{3}$ ) vooral ook concordantiëel bekijkt, komt gelijk al tot de ontdekking dat het gebruik op een aantal groepen van teksten wijst.

(a) $\mathrm{Er}$ is allereerste hoop bij Paulus, de andere apostelen en de medewerkers, dat zij in de groei van de gemeente en in het liefdebetoon van de gemeente en in de toename in geloof van de gemeente niet beschaamd zullen worden. Want de gemeente en wat er in en aan haar gebeurt, is het werk Gods en alszodanig de hoop der apostelen. Aan de vindplaatsen gaan we verder voorbij, omdat ons de, extern gerichte' hoop meer interesseert. Straks zullen wij van de, intern gerichte' hoop nog horen.

(b) Er is een onderscheid tussen hoop op God en Christus, en God en Christus Die onze hoop vormen. De ethnè zullen op de Naam van de Knecht des Heeren hopen (Matth. 12:21), ja de heidenen zullen op Hem hopen (Rom. 15:12) Die opstaat om over de heidenen te gebieden. Alleen in dit leven op Christus hopen, d.w.z. de hoop op Christus beperken, maakt ons de ellendigste van alle mensen ( 1 Kor. 15:19). Wij hopen in ons werk op de levende God Die een Behouder is van alle mensen, maar allermeest der gelovigen (I Tim. 4:10). Een weduwe is werkelijk weduwe, wanneer zij op God hoopt en zo ook haar leven inricht ( 1 Tim. 5:5), trouwens, dat wordt in I Petr. 3:5 van de ,heilige vrouwen' gezegd, van wie Sara er een is. Zoals in I Tim. 6:17 de rijken van de hoogmoed en het vertrouwen op hun ongestadig bezit worden afgekeerd en hun bevolen wordt op God te hopen, Die ons alles rijkelijk verleent om te genieten (I Tim. 6:17). Opvallend dat van al deze teksten eigenlijk alleen I Kor. 15:19 de hoop op Christus uitbreidt naar het leven buiten dit leven, of liever: Christus voorstelt als Een Die ons meer te hopen geeft dan dit leven. Voor het overige richten teksten de aandacht bij hoop sterk naar het interne gemeenteleven.

(c) De derde gres, wordt gevormd door die plaatsen, waar God en Christus zelf als de hoop worden voorgesteld. Rom. 15:5 en 13 stellen God voor als de God van hupomoné, paraklèsis en elpis. En door die God der hoop en Zijn vervulling van ons met blijdschap en vrede in het geloof worden wij overvloedig in de hoop. Col. 1:27 - wat altijd verborgen is geweest, is nu door de bediening van het Woord via Paulus vervuld en geopenbaard, nl. Christus onder $u$, de Hoop der heerlijkheid. En I Tim. $1: 1$ - Paulus is apostel naar het bevel van God en Jezus Christus, Die onze Hoop is. En hij schrijft naar dat bevel aan Timotheüs. Christus Die onze Hoop is, vormt dus de verbinding

3) Het summier karakter van Bultmanns artikel s.v. in Kittels Th. W.N.T. II noodzaakt ons de teksten te laten spreken. 
tussen schrijver en geadresseerde. Ik neem aan, gezien de veelheid van keren dat elpis in de pastorale Brieven ter sprake komt, dat deze benaming van Christus aan het begin van deze Brief zeer zewust gekozen is en betekent dat de ambtsuitoefening gezien wil worden onder het aspect van de hoop in de eerste plaats. Opnieuw moeten wij konstateren wat ook bij de tweede groep teksten bleek, dat de hoop, direkt verbonden met God de Vader en de Zoon, zich richt op het leven der gemeente, dat groeit in het Woord. Dit neemt niet weg dat een tekst als Col. 1:27, over die openbaring der verborgenheid onder de heidenen van Christus de Hoop der heerlijkheid, impliceert dat in Christus te hopen valt voor de heidenen op het herkrijgen van hun bestemming in de heerlijkheid Gods. Het gaat er immers Paulus om, dat door de prediking van Christus als de Hoop der heerlijkheid ieder mens volmaakt in Christus gesteld zal worden (vs. 28). Zo komt het ook als het eigen werk van Christus in vs. 22 voor, en er is geen beletsel om dat op te vatten als een eschatologische notie. Ik teken daarbij aan, dat we dus hier iets ,concreets' tegenkomen. De prediking van de openbaring van de Hoop der heerlijkheid wil de mens, ieder mens, volmaakt in Christus stellen, zoals ook Christus de heidenen die vervreemd waren, de gelovigen te Colosse, in Zijn dood verzoend heeft, opdat $\mathrm{Hij}_{\mathrm{ij}}$ hen heilig, onberispelijk en onbeschuldigbaar voor Zich zou stellen. Dit ,concrete' verwerkelijkt zich nu op de wijze van het geloof, want Paulus verkondigt de mensen Christus als de Hoop der heerlijkheid en vermaant en onderwijst hen, ópdat hij ieder mens volmaakt in Christus stelt.

(d) Dan is daar een groep van teksten die spreekt van de hoop van Israël en waarvan we mogen zeggen, dat daarin de beloften van God aan Israël in het N.T. terugkeren. In Luk. 24:21 belijden de Emmaüsgangers aan Jezus: „En wij hoopten dat Hij was Degene Die Israël verlossen zou." Plummer heeft in de ICCcommentaar op Lukas erop gewezen dat "wij" (hèmeis) met zekere nadruk in deze tekst voorkomt. Onze overpriesters en oversten hebben Hem overgeleverd tot het oordeel van de dood en Hem gekruisigd, en wij hoopten dat Hij was ... Bijvoorbaat staat dus het denken van de discipelen in lijnrechte tegenstelling tegen cie geestelijke leiders en leden van het Sanhedrin. Maar in die tegenstelling nemen de discipelen, geleerd door Jezus Zelf, het Oude Testament te baat, dat vervormd was door rabbijnse interpretaties. Echter, hun geloof in Jezus als de Vervuller van de Oudtestamentische belofte en verwachting stuit op de realititeit van Zijn sterven aan het kruis. In Joh. 5:45 komt eigenlijk een soortgelijke teneur openbaar, wanneer Jezus tot de loudaioi zegt: „Meent niet dat lk u aan- 
klagen zal bij de Vader; die $u$ aanklaagt, is Mozes, op wien gij gehoopt het." In dubbele zin functioneert Mozes hier: als samenvatting van de Wet, èn als persoon, misschien wel hun voorspraak ( $\mathrm{vgl}$. Joh. 7:19 en 9:28). Zij noemden zich immers discipelen van Mozes. Ongetwijfeld doelt Jezus hier op het gericht voor God; Hij spreekt immers van een anklager (katègoroon). Dan heeft de hoop dus de inhoud van hoop op advocatuur, voorspraak, bijstand in het gericht. Zoals in Hand. 26:6-7, waar sprake is van de hoop der belofte die door God aan de vaderen geschied is, over welke hoop Paulus geoordeeld wordt, die hoop en belofte ook geheel in het verband van de opstanding der doden staat. Want Paulus laat ongenblikkelijk na de beschuldiging over die hoop der belofte door de Joden vermeld te hebben, volgen: „Wat! Wordt het bij ulieden ongelofelijk geoordeeld dat God de doden opwekt?" Hier hebben wij de notie dat de verwachting van Israël zich door het getuigenis en leven van de apostel voortzet tot de opstanding der doden, en zo geldt het mutatis mutandis ook het karakter van de Oudtestamentische belofte. Later, in Hand. 28:20, wanneer Paulus de leidinggevende Joden te Rome in zijn woning heeft uitgenodigd, herhaalt zich hetzelfde: „Vanwege de hoop van Israël ben ik met deze keten omvangen". Hetzelfde doet zich voor in Hand. 24:15 en 21 en vooral in Hand. 23:6, waar Paulus de hoge raad in verwarring brengt door te roepen: .Ik ben een Farizeeër... ik word over de hoop en opstanding der doden geoordeeld". Wij mogen dus gevoeglijk stellen, dat de gemeente van Jezus Christus heeft geleefd in de hoop op de opstanding der doden en daarbij geruggesteund werd door de wetenschap van de belofte aan Israël met déze inhoud. Zoals trouwens in Handelingen de prediking als centraal thema de opstanding van Jezus Christus heeft en de opstanding der mensen met aanhaling van tal van beloften uit het O.T.4)

Bovendien valt daarbij te zeggen, dat met name in Handelingen de hoop en belofte van Israël, welke de opstanding raken, beurtelings gebruikt wordt om Israël te overtuigen (zie bepaalde delen in Rom. 9-12), dan weer om Sadduceeërs en Farizeeërs met list tegenover elkaar te setten, en tenslotte om de prediking van de opstanding aan te heidenen, die voor hen dwaasheid is (Hand. 17 en I Cor. 1), met gezag van de beloften Gods aan Israël te staven. Wij tekenen hierbij aan dat het tweede concrete van de Nieuwtestamentische eschatologie de opstanding der doden omvat en alszodanig een welkome aanvulling is op wat bedoeld wordt met de strekking der verkondiging om elk mens volmaakt in Christus te stellen.

4) Hand. 2:26 e.v. en I Thess. 4:13: de hoop raakt degenen die ontslapen zijn. 
(e) We gaan op dit spoor verder en komen tot een groep van teksten die de relatie leggen tussen roeping, belofte en hoop. Van Abraham, „onze vader”, stelt Rom. 4:18 dat hij tegen het vlees in (vs. 1) en tegen hoop op hoop geloofd heeft dat hij een vader van veel volken zou worden volgens wat gezegd was: „Alzo zal uw zaad zijn." Hij heeft aan de belofte van God niet getwijfeld door ongeloof (vs. 20), hoewel elke ,berekening' van deze hoop op onmogelijkheden stuitte zowel bij hemzelf als bij Sara. Paulus bidt (Ef. 1:18) voor de gemeente van Efese om verlichte ogen van verstand om te weten wat de hoop is van Gods roeping, en wat de rijkdom is van de heerlijkheid van Zijn erfenis in de heiligen. Of, zoals het N.B.G. vertaalt: welke hoop Zijn roeping wekt, hoe rijk de heerlikheid is Zijner erfenis bij de heiligen. Meestal vat men die woorden „bij de heiligen” op als gold het de christenen hier en toen. Ik houd het voor mogelijk dat eerder gedacht wordt aan wat Coloss. 1:12 bedoelt: "De Vader heeft ons bekwaam gemaakt om deel te hebben aan de erfenis der heiligen in het licht", zodat het kan slaan op de erfenis temidden van Gods ,hemelgenoten', die voor de gelovigen bij God bewaard wordt (I Petr. 1:4). In dat geval richt de hoop, door Gods roeping gewekt, zich door dit leven heen op volmaakte heerlijkheid, op het erven van God en het meeërven met Christus, op het met Hem verheerlijkt worden (Rom. 8:17). Ef. $4: 4$ benadrukt dan de eenheid van die hoop, die uit de roeping van God voortgekomen is. Hier blijkt dat zowel aan het transcendentale als aan het immanente te denken valt bij roeping en hoop. Want is het een uitgemaakte zaak, dat de apostel hier niet kan bedoelen: gij zijt geroepen tot eenheid in de hoop? En ook dán is de hoop zowel een bron van gemeenteleven nu als een richting op de toekomst des Heeren. De gemeente - wil de tekst dan zeggen - is één in het lichaam van Christus, in de Geest, in Christus en in de Vader, in de doop, in het geloof, doch niet minder in de hoop van uw roeping. Daartoe zijt ge geroepen.

Heel duidelijke teksten zijn in dit verband een drietal uit Titus. Titus 1:2-God Die niet liegen kan, heeft de hoop van het eeuwige leven beloofd vóór de tijden der eeuwen, ${ }^{5}$ ) maar geopenbaard te Zijner tijd. En dan blijkt dat de apostel die hoop en die belofte gelijkstelt (vs. 3) met het Woord. U kunt de zin zo lezen: God heeft sedert onheugelijke tijden de hoop van het eeuwige leven beloofd, maar Hij heeft Zijn Woord geopenbaard te Zijner tijd in de verkondiging die ook Paulus is toevertrouwd. Dit onthouden wij dus, dat de openbaring der hoop op het eeuwige leven geschiedt in het Woord der verkondiging. In 2:13

5) Vgl. 2 Tim. 1:9 - zover kunt ge niet teruggaan of deze belofte gaat verder terug; een contractie van de moederbelofte en de eeuwige raad van God. 
stelt Paulus dan in dezo zelfde Brief de zalige hoop en verschijning der heerlijkheid van de grote God en onze Zaligmaker Jezus Christus in het verschiet van het matig, rechtvaardig en godzalig leven in deze tegenwoordige wereld. De woordkeus verraadt reeds dat ,olaam habbah bedoeld is bij die zalige hoop en verschijning. Zo ook in 3:7 - God heeft ons zalig gemaakt opdat wij, gerechtvaardigd door Zijn genade, erfgenamen zouden worden naar de hoop van of op het eeuwige leven. Het lijdt geen twijfel of volgens deze teksten reikt de hoop verder ook dan de opstanding. Zij richt zich op de verschining van Jezus Christus in heerlijkheid, en daarachter op een ándere bedeling, namelijk die van het eeuwige leven. $\mathrm{Zij}$ die stellen dat Nieuwtestamentisch ha'olam habbah reeds begonnen is in de opstanding van Jezus Christus uit de doden, mogen gelijk hebben, ${ }^{6}$ ) dit neemt niet weg dat de kwestie van verderfelijkheid en onverderfelijkheid ( 1 Cor. 15 en 2 Cor. 5) de overgang bij de verschijning van Christus tot een inhoudelijk belangrijk punt van de Nieuwtestamentische hoop maakt. En het is niet onjuist om steunend op veel teksten in de Brieven dit deel der hoop te omschrijven met het begrip erfenis.

(f) Tenslotte: wat de gemeente nú heeft te doen in die hoop, heet in het N.T. voornamelijk hupomonè, geduld en volharding. Rom. 8:25 - Indien wij hopen wat wij niet zien, dan verwachten wij het met hupomonè. Rom. 12:12 — de woorden .,verblijdt $u$ in de hoop" staan in één verband met „zijt geduldig (hupomenontes) in de verdrukking". Rom. 15:4 en 13 — "Al wat tevoren geschreven is, dat is tot onze lering tevoren geschreven, opdat wij door hupomonè en paraklèsis van uit de Schriften hoop hebben zouden", en :,De God nu der hoop vervulle ulieden ... opdat gij overvloedig moogt zijn in de hoop door de kracht van de Heilige Geest". Het blijkt dat de hoop terugslaat op de verdrukking der christenen als geduld en volharding. Waarin volharding? In het verwachten van wat we niet zien. Andere notieskomen daarbij uit de Brief aan de Hebreeën, waar deze kant aan de hoop een gedurig thema is. Hebr. 3:6- wij zijn Christus' huis, indien wij maar de vrijmoedigheid en de roem van de hoop tot het einde toe vast behouden.

Hebr. 6:11 - ieder van de Hebreeën moet dezelfde naarstigheid of ijver blijven bewijzen tot de volle verzekerdheid ${ }^{7}$ ) der hoop tot het einde toe, opdat gij niet traag wordt, maar navolgers zijt dergenen die door geloof en makrothumia ${ }^{8}$ ) de beloften beërven. In deze tekst hebben we alle gegevens bij elkaar.

6) Zie W. D. Davies, Paul and rabbinic Judaism, London 158, p. $298 \mathrm{ff}$.

i) plèrophoria - verwerkelijking - vertaling Nederlands Bybelgenootschap, geheelheid - Rienecker.

8) geduld, lankmoedigheid; geduld-Rienecker; want hier en in vers 15 gaat de hoop in geduld over. 
ljver, geduld, hoop, belofte, erfenis. In vers 18 wordt daar op grond van de onder ede bevestigde belofte Gods aan toegevoed: wij hebben de toevlucht genomen om de voorgestelde hoop vast te houden welke wij hebben als een anker der ziel, dat zeker en vast is en ingaat in het binnenste van het voorhangsel, waar de Voorloper voor ons is ingegaan, namelijk Jezus ... IJ.B.G.: wij hebben een krachtige aansporing (in die eedzwering van God) om de hoop te grijpen, die voor ons ligt. Haar hebben wij als een anker der ziel, dat veilig en vast is, en dat reikt tot binnen het voorhangsel ... enz. De taal is duidelijk die van het hemels heiligdom. Jezus is er de Bedienaar van. Maar in de hoop op de eed van God en de belofte van Godtwee onveranderlijke dingen! - volgen wij Hem daar waar geen mens mag volgen. In de hoop hebben wij dus een anker tot in de hemelse tabernakel. In de hoop hebben wij ons politeuma in de hemelen. Ook in 7:19 is ce hoop de weg om tot de hemelse God 1e komen. Hebr. 10:23 spreekt tenslotte van een onwankelbare belijdenis der hoop die wij moeten vasthouden, ofwel van een onwankelbaar vasthouden aan de belijdenis van wat wij hopen, zoals ook I Petr. 3:15 aanspoort verantwoording af te leggen aan ieder die $u$ rekenschap afeist, van de hoop die in $u$ is.

Duidelijk is ons in deze laaste groep wel geworden; dat de hoop de bestaansiv jze van de christelijke gemeente omvat, waarvan het geduld en de volharding, het wandelen door geloof en niet in aanschouwen ( $w: j$ hopen wat wij niet zien), het geduld in het bijzonder in de verdrukking, het politeuma in de hemelen en het ingzan achter Jezus tot achter het voorhangsel( het weten van de aanvaarding der verzoendheid door God) de segmenten zijn. Is dit niet het zoveclste concretum aan cle hoop. nu op het interessante vlak: wat heeft de hoop met dit laven, deze wereld, deze schepping, vooral deze mensen en hun dagelijks bestaan te maken?

Ons is uiteraard opgevallen, dat althans sub voce hoop en hopen het N.T. geen of nauwelijks materiaal biedt tot uitwerking van de christelijke hoop naar de wereld toe, anders dan in getuigenis en belijdenis en het eigensoortig bestaan der gemeente op deze aarde. Het antwoord dat de teksten ons leverden op de vraag: Is eschatologie concreet?, luidt als volgt. De prediking van Christus de Hoop der heerlijkheid bedoelt ieder mens volmaakt in Christus te stellen op de dag van Zijn toekomst, maar die volmataktheid wordt alleen ,bereikt' door en voor het geloof. Deze prediking neemt ten aanzien van Jood en heiden het hele in Christus Jezus vervulde Oude Testament onder het aspect der belofte te baat om de zeker- 
heid der hoop te staven. Verder vindt de hoop zekerheid in de liefde (Rom. 5:5 en I Cor. 13:13). Door heel het N.T. heen is de hoop verbonden met de opstanding der doden en met het gericht Gods. In het laatste geval richt de hoop zich op de advocatuur van Christus en de Geest. Zij staat immers in de context van de paraklèsis, en Christus en de Geest heten beide Paraklètos. Hoop is zowel een immanente als een transcendente zaak. $U$ zoudt kunnen denken aan het futurum en de adventus van Moltmann. Alleen vrees ik dat althans volgens déze woordgroep, waar ik me thans toe wil beperken, voor de seculaire betekenis van futurum s.v. hoop in het N.T. geen grond aanwezig is. Onder het hoofd ,erfenis' is goede grond gelegen om ha'olam habbah en ha'olam hadzè van elkander te onderscheiden zonder die te scheiden, en om voor een toekomstige 'olam ruimte te maken in de christelijke toekomstverwachting. De opstanding van Jezus Christus uit de doden doet de caesuur van wederkomst en opstanding der doden niet teniet, hoewel zij met elkaar als oorzaak en resultaat, onderpand en verlossing verbonden zijn. De hoop is de bestaanswijze van de christelijke gemeente, onder het aspect van geduld en volharding daar waar zij haar politeuma heeft $\mathrm{nl}$. in de hemelen, en daar waar zij haar vreemdelingschap (Hebr. 11) heeft $\mathrm{nl}$. op de aarde. ${ }^{9}$ )

II. Een enkel woord over dogmatische implicaties. Aan het begin stemde ik in met Graafland dat de vraag: Is eschatologie concreet?, een hemeneutische vraag is. Maar wat betekent hermeneutiek? Gaat het in hermeneutiek alleen om regels en methoden van Bijbeluitleg, of wordt vandaag de dag hermeneutiek gebruikt als toverwoord op het scheid van Woord en werkelijkheid, van de verhouding der Schriften tot het bestaan van de mens, meer nog: van de relatie der Schriften tot de ideologe van het humanum? Een voorbeeld van dit soort kwalijke hermeneutiek is wat Ter Schegget schrijft in Het geheim van de mens, Baarn 1972, blz. 84-85: „Tegenover deze lichtzinnige illusies is alleen een militant humanisme.... dat Gods bedoeling met de mens ernstiger neemt dan alle traagheid en zelfzucht in het verleden, werkelijk realistisch te noemen. In de belofte ligt de grond van de werkhypothese der hoop! De tekst van Johannes, die wij reeds aanhaalden, luidt volledig aldus: ,Het is nog niet geopenbaard wat we zijn zullen, maar wij weten, dat als $\mathrm{Hij} z a l$ geopenbaard zijn, wij Hem gelijk zullen wezen' en even verder: ,een ieder die in Hem blijft, zondigt niet' (I Joh. 3:2,6). Daartoe is de mens bestemd! Als dit zijn geschonken bestemming is en als zo zijn toekomstige werkelijkheid is, dan moet op grond daarvan de reële mogelijkheid van zijn volmaking in het heden worden gesteld. Religie leert berusting. Geloof maakt militant. Religie is ten diepste

9) ksenoi kai parepidèmoi, Hebr. 11:13. 
wanhoop. Geloof is hoop". Wat voor hoop echter? ${ }^{10}$ ) „Een slechte erfzondeleer bemantelt verdrukking en uitbuiting. $\mathrm{Zij}$ is een ideologisch produkt van de klassemaatschappij. Daarom willen wij er niet mee van doen hebben". Dit soort ontlening van hermeneutische regels aan een van tevoren vaststaande taxatie van de werkelijkheid is vals en wórdt vals en gemeen, wanneer zin in Schriftwoorden gaat spreken.

Ik heb hier een speciale exponent genoemd van slechte hermeneutiek, namelijk Ter Schegget. Belangrijker is echter wat de aanleiding vormt tot dit soort indoctrinatie, namelijk de vraag: in hoeverre heeft de christelijke hoop van doen met déze aardse werkelijkheid, wat hoopt ze daarvoor? Inhoeverre keert zij zich van deze aardse werkelijkheid af? En wat heeft dat te betekenen voor de relatie tussen deze en de toekomende wereld? Ofwel: wat betekent in bijbelse zin ,concreet'?

Wij hebben uit de Bijbel te verstaan gekregen dat de hoop voor déze bedeling wel ter dege meespreekt voornamelijk als bestaanswijze der gemeente. Het is dus niet zo vreemd wanneer Graafland in het aangehaalde artikel het gelukkig noemt dat de chiliastische lijn, ook al zou zij van doperse origine zijn, nooit geheel ontbroken heeft in het gereformeerd protestantisme. ${ }^{11}$ ) Waarbij overigens aan te tekenen valt dat Taverne in het algemeen wel gelijk heeft, wanneer hij in zijn blad Uitzicht telkens betoogt dat het pre-chiliasme (waarbij er ook nog een aan het duizenjarig vrederijk voorafgaande komst van Christus is) sektarisch is en dat in de Kerk het postchiliasme (door Bunyan $\in$ O Owen e.a. ijverig voorgestaan) legitiem was en is. Ik ga nu niet op de hele geschiedenis van Openb. 20 en zijn exegese in, vraag alleen: welke componenten hebben bijgedragen tot het chiliasme? Behalve exegetische motieven heeft de verwachte bekering der Joden heel veel voor de ontwikkeling van het chiliasme betekend. Dit houdt tevens in dat wij het chiliasme althans rond de zeventiende eeuw, op gereformeerde en niet op lutherse bodem moeten zoeken, ${ }^{22}$ ) aangezien andere vertakkingen van het protestantisme niet of nauwelijks aandacht hadden voor de toekomst van het Joodse Volk. Het betekent ook een opdracht voor elk eschatologisch ontwerp in het heden. Ik laat nu dwepers, zoals opgesomd in Evenhuis' Ook dat was Amsterdam en Zilverbergs Geloof en geweten in de zeventiende eeuw, maar buiten beschouwing. Een tweede component tot ontwikkeling van het chiliasme vormde het ontwaken van missionair bewustzijn in de wereld. Hoe gaat het plèrooma der volken in in het Koninkryk Gods? Welke tijden breken

10) Is het toevallig dat het zowel om een militant humanisme draait als om een geloof dat militant maakt? Van toen af werden Pilatus en Herodes vrienden. Inmiddels neem ik gaarne aan, dat Ter Schegget onder ,huma-

11) Blz. 293 .

12) Zie lain Murray, The Puritan Hope, London 1971, passim. 
er voor de heidenen aan, wanneer hun het Evangelie verkondigd wordt en zij het aannemen? Zullen dan hun structuren van bestaan en samenleving nie zó gewijzigd worden, dat het Godsrijk reeds nu gestalte aanneemt onder de volken? Een derde component die het chliasme bevorderde, was en is de secularisatie. Neergang, verwereldlijking, reveil, belijdenis van de regering Gods in een nabij vrederijk: ze gaan bijna altijd samen, zij het op verschillende manieren.

Toch heeft een groot deel van de Kerk altijd huiverig gestaan tegenover dit soort verwachtingen, die al dan niet met concrete datering werden opgesierd. Hoe komt dat? Ongetwijfeld speelde in de argwaande vervloeiing der grenzen mee, ongetwijfeld ook wat reeds in de trew vermahnung van Luther aan de oproerige boeren het devies was: geen oproer of agitatie want „auss ubel wirt ergers". „Der mund Christi musz es thun." Wie hier de behoudendheid van Luther tegenover de Middeleeuwse maatschappij in het geding brengt, vergist zich m.i. schromelijk. Het ging Luther niet om het kiezen van een type maatschappij. Hij zou de maatschappij der toekomst wel zien vanuit de kracht van het Woord, maar hij vreesde - niet zonder reden - dat oproer in deze zin niets met geloof, hoop en liefde te maken had. Voorwaar een tegengesteld hermeneutisch principe als dat van Ter Schegget!

Voor ons zijn daarmee echter de dogmatische vragen niet uitgeput. Welke relatie blijft er nu over voor de toekomstverwachting tussen deze en gene wereld, 'olam hadzè en 'olam habbah? Of stel ik de vraag verkeerd? Is 'olam hadzè in menig Nieuwtestamentisch geval het inbegrip van christelijk geloof in de bedeling nu? Dat zou dan ook nog een scheiding teweegbrengen tussen Kerk en wereld in deze bedeling. Is dat alles gewettigd? De teksten die wat de hoop betreft, terugwezen naar deze bedeling, verwezen ontegenzeggelijk naar de gemeente en haar gered-zijn-in-hope. Dat is de wijze van haar bestaan. Daarnaast wijst men gaarne op Rom. 8, waar sprake is van de barensnood van de ktisis. Die barensnood nu moet dienen om de sonen Gods te openbaren: dat is wezenlijk wat anders dan de aanneming tot zonen Gods, welke zij verwachten die de eerstelingen van de Geest hebben. Voeg daarbij, dat de heerlijkheid die aan ons (de christenen) geopenbaard sal worden, niet is te waarderen tegen, niet opweegt tegen het lijden van de kairos nu, en $u$ komt tot de conclusie dat er toch wel een fundamenteel verschil bestaat tussen wat meewerkt aan de openbaring der zonen Gods en wie de aanneming tot kinderen verwachten door de Geest.

Levert echter vs. 21 - op hoop: daarom dat ook de schepping, de ktisis zelf van de dienstbaarheid aan het verderf zal worden bevrijd tot de vrijheid van de heerlijkheid der kinderen Gods - toch méér hoop op, dan dat de ktisis alleen maar dient tot openbaring der zonen Gods? Is met die ktisis de mensenwereld bedoeld of de hele bedeling nú, die dan vernieuwd zal worden, gelouterd en gezuiverd, 
maar toch haar identiteit door het gericht heen bewaart ${ }^{13}$ ) In dat laatste kan, zoals bij Berkhof, ${ }^{14}$ ) nog wel voornamelijk het zuchtende schepsel bedoeld zijn, i.p.v. de schepping. Opvallend is tegelijk, dat Berkhof nu, in zijn laatste werk, met meer terughouden theid dan in Christus de zin der geschiedenis, wil spreken over de grens van 'de ons verplichtende gezaghebbende bedoeling van deze enorme beelden (c.q. antichrist en duizendjarig rijk - CAT) op het projectiescherm van de toekomst. ${ }^{15}$ ) De grens van de vernieuwing in de relatie tussen Geest en wereld bestaat volgens hem niet (zoals in de relatie tussen Geest en mens) in een afsterven en een uitsterven van de mensheid (.,daarover kunnen we tenminste geen geloofsuitspraken doen"), maar in een verheviging die vastloopt in een verhevigde en niet te overwinnen ambivalentie van Geestkracht en tegenkracht. Het lot van Jezus Christus de Gekruisigde èn Opgestane wordt op die wijze en tot die grens straks wereldwijd in het wereldlot weerspiegeld. ${ }^{10}$ )

Ik meen, dat Berkhof gelijk heeft wanneer hij de ordo salutis ad eschaton in het ménsenleven op een andere manier beschrijft dan in het bestaan en de ontwikkeling van de ktisis. Ook kan ik me voorstellen dat hij woorden als ,verheviging' en ,spronggebeuren' gebruikt, wanneer hij de continuïteit met en Goddelijke wending aan deze geschiedenis naar de toekomst door Gods gericht heen wil uitdrukken. Toch vraag ik me af, of hij daarmee de Schriften recht doet. Alleen al dat begrip ,geschiedenis'! Is alleen op de manier van 'geschiedenis' de ktisis betrokken in het zuchten, reikhalzend verlangen en openbaarmaken van de zonen Gods? Dan die gebruikte termen. Wanneer hij zegt ${ }^{17}$ ) dat wij over discontinuiteit en continuiteit tussen geschiedenis en gericht Gods onmogelijk anders dan in beelden kunnen spreken, waarom dan die beelden van antichrist en duizendjarig rijk, die Berkhof wezenlijk acht „voor het geloof aan een echte relatie tussen de gekruisigde en opgestane Christus en de wereld", ${ }^{18}$ ) niet gebruikt om niet slechts het geloof naar de kant der hoop, doch ook de werkelijkheid, historisch en ruimtelijk en planetair naar de kant der hoop te omschrijven? Of worden we hier ineens teruggeworpen op het bestaan der gemeente in hope, ${ }^{10}$ ) die daarover haar eigen taal spreekt en haar eigen onderlinge 'Verständnis' heeft? Kan dat vanuit de Godsleer worden volgehouden, dat het spreken over de wereld en wat in en met en op haar gebeurt en gebeuren zal, niet door geloof en door de Geest in alle gebrekkigheid bevat dat gene wat God realiter aan en met deze werkelijkheid doet en doen zal?

13) H. Berkhof, Christelijk geloof, Nijkerk 1973, blz. 540 e.v.

14) o.c., blz. 506 .

15) blz. 539.

16) o.c., blz. 539-540.

17) blz. 541 .

18) blz. 539.

19) Bultmann, Th. W.N.T. II, S.528. 
Graafland heeft gewezen op de reformatorische tussenweg tussen Rooms synergisme en wetticisme met bijbehorende heilsonzekerheid, en Dopers anteciperen op het heil door een synergistische realisering van het heil in deze wereld..$^{20}$ ) $\mathrm{Hij}$ beweert dat het denken en leven uit de rechtvaardiging ook voor de eschatologie het aandeel van de mens in het heil ontkent. Dat betekent dat het heil in deze wereld niet op een andere wijze dan die van de rechtvaardiging present is, nl. als geloofswerkelijkheid. ${ }^{21}$ ) En het zal, zonder dat wij de implicaties hier uitwerken, duidelijk zijn dat deze ,stelling' heel wat betekent voor de vraag, op welke wijze de wereld participeert in het toekomstig heil. Wanneer nu de vreemdheid van het heil, ingebed in en volgend uit de vreemde vrijspraak, niet voldoende wordt onderkend, dan vervloeien eschaton en futurum. ${ }^{22}$ ) De vreemdheid van het heil ligt in de rechtvaardiging door het geloof, zonder aandeel van de mens in het heil, en in de radicale toekomstigheid van het heil, nl. als recreatio e nihilo. ${ }^{23}$ ) Het valt te verstaan dat Berkhof zover niet gaat. Hij acht het denken aan de toekomst als bij uitstek of uitsluitend die van een nieuwe volmaakte samenleving waarin onze mensheidsgeschiedenis zal uitmonden, een onaanvaardbare reductie van de christelijke verwachting omwille van de strekking van heel de heilsopenbaring en in het bijzonder omwille van de opstanding van Jezus als belofte en onderpand voor ons. ${ }^{24}$ ) Tegelijk houdt hij het ervoor dat het interesse uitsluitend voor de individuele ziel in verschillende beschouwingen rond de zgn. tussentoestand (de zieleslaap en andere voorstellingen) evenzeer een reductie van die verwachting is, omdat in deze gevallen de vraag hoe God met de wereld klaarkomt, nauwelijks meer interessant is. „Over een tussentijd en een tussen-toestand kunnen wij geen zinnige uitspraken doen." 25 )

Dat is uiteraard maar weer hermeneutisch de vraag, wanneer Schriftgegevens vooral in tijden van druk op de Nieuwtestamentische christenheid, de gemeenten wilden vertroosten, ook over die tussentoestand.

Zo is het ook de vraag of Berkhof de opstanding der doden het begrip of beeld tot expressie van totale toekomst in het christelijk geloof noemt en daarmee slechts wil tot uitdrukking brengen dat het hier gaat om een geloofsvoorstelling, een geloofsverwachting, of dat hij de mogelijkheid verdisconteert in die woorden ,begrip' en ,beeld' dat de werkelijkheid der toekomst er ánders uit zal zien dan in het gelóóf verwacht werd. Ik kan me na zijn boek Gegronde verwachting nauwelijks voorstellen dat hij dit laatste zou bedoelen.

\footnotetext{
20) blz. 307 .

21) blz. 307 .

22) Bewust een andere terminologie dan die van Moltmann, W. D. Marsch e.a. die onderscheiden tussen ,futurum' en ,adventus'.

28) blz. 309 .

$24)$ blz. 548 .

25) Ibidem.
} 
Ook de punten, die hij in Christelijk geloof opsomt als componenten van die christelijke toekomstverwachting (relatie tussen Jezus' opstanding en onze toekomende bevrijding; verband met wat de Geest regenererend en recreërend aan ons doet in dit leven; discontinuiteit met al het tevoren bereikte: breuk en een nieuw wonder zonder eigen reserves als die van, een onsterfelijke ziel'; ${ }^{28}$ ) continuiteit met ons aardse bestaan in onze identiteit; totale vernieuwing vervat in ,opstanding), zijn werkelijkheden en worden in het geloof verwacht. ${ }^{27}$ ) In dit opzicht zullen Berkhof en Graafland elkaar niet bijten. „Met het woord opstanding belijden wij dus samenvattend, dat het mensenbestaan niet wordt afgestoten en evenmin wordt vereeuwigd. Het wordt vernieuwd naar analogie van Jezus die vanuit ons oude bestaan opstond tot een nieuw leven. Wij bereiken ons doel dus niet door verticaal te ontsnappen en evenmin door horizontaal door te draven. Heel het bestaan van mensen en mensheid wordt door en radicale vern'euwing heen gered, bewaard en vruchtbaar gemaakt." ${ }^{28}$ ) Dit breidt hij uit tot nagenoeg al ,die talloze anderen die niet in deze verbondsrelatie hebben geleefd' (scl. van het geloof - CAT). Niet de verdrukten, niet de barmhartigen, ook niet de onbewusten, slechts Gods tegenstanders, dat zijn zij die de gangen van Gods verkiezing en liefde weerstaan, hebben het gericht te duchten als volstrekte veroordeling. ${ }^{28}$ ) $\mathrm{Nu}$ zie ik ineens en geweldige breuk tussen enerzijds Berkhof, die onderscheidt naar het leven tussen onbewusten, barmhartigen, verdrukten onder de mensen die niet in die verbondsrelatie hebben geleefd, èn de echte tegenstanders die ook niet in die verbondsrelatie hebben geleefd, en anderzijds Graafland die de zaak van God uit als vreemde vrijspraak en radicale toekomstigheid van het heil beschrijft. Bovendien gaat mij een licht op, wanneer ik lees bij Berkhof, dat het mensenbestaan naar zijn verwachting wordt vernieuwd naar analogie van Jezus, die vanuit ons oude bestaan opstond tot een nieuw leven. Ik betwijfel of hij hermeneutisch wel het recht aan zijn kant heeft in die analogie. Is Jezus overal en altijd in het N.T. en vooral ook in de opstandingsberichten de Mens voor en namens ons allen en heel de mensheid? Is Hij geheel en uitsluitend pars pro toto? Of is Hij ook Degene aan Wien de Vader al het oordeel heeft overgegeven? Dan waag ik te stellen dat in de eschatologe niet maar naar analogie, doch op grond van de opstanding van Jezus totaliter aliter, namelijk salvificax, reddend de Heere God de mens doet opstaan en hem stelt in de heerlijkheid bij Zichzelf om Zijns Zoons wille. Ons uitermate-verhoogd-worcien is genadedaad, die verhoging van Jezus Christus echter verdienste op grond van Zijn kenoosis (Philipp. 2:9).

26) Een misvatting van Berkhof jegens het kerkelijk belijden, dat God terstond het leven der zijnen tot zich neemt! Dat is niet allereerst uit de soomasèmaidee geboren.

2-) blz. 549-550.

28) blz. 550 .

29) blz. 552 


\section{BESLUIT}

Inderdaad is eschatologie een zaak van hermeneutiek. Inzoverre wij weinig aandacht hadden voor de betrokkenheid van deze werkelijkheid op de toekomstige, moeten ons deze vragen dringen. Doch de regels en methoden, in de hermeneutiek en exegese geldig, kunnen slechts aan de Schrift zelf ontleend zijn. Zoals ook de werkelijkheid hier en nu niet rechtstreeks doch indirekt via de gemeente en gemeenschap der heiligen meedoet in de eschatologie. Alle andere vragen en antwoorden over gegronde of ongegronde verwachting zijn onderworpen aan deze principia, die de concreetheid van de hoop bepalen. 